\title{
BIOMASS BURNING RELATED POLLUTIONS AND THEIR CONTRIBUTIONS TO THE LOCAL AIR QUALITY IN HONG KONG
}

\author{
K. L. Chan ${ }^{\mathrm{a},},{ }^{*} \mathrm{~K}$. Qin $^{\mathrm{b}}$ \\ ${ }^{\text {a }}$ Meteorological Institute, Ludwig-Maximilians-Universität München, Munich, Germany - lok.chan@lmu.de \\ ${ }^{\mathrm{b}}$ School of Environment Science and Spatial Informatics, China University of Mining and Technology, Xuzhou, China - qinkai@cumt.edu.cn
}

Commission III, WG III/8

KEY WORDS: biomass burning, source contributions, long range transport, black carbon, carbon monoxide

\begin{abstract}
:
In this study, we present a quantitative estimation of the impacts of biomass burning emissions from different source regions to the local air quality in Hong Kong in 2014 using global chemistry transport model simulations, sun photometer measurements, satellite observations and local monitoring network data. This study focuses on two major biomass burning pollutants, black carbon aerosols and carbon monoxide (CO). The model simulations of atmospheric black carbon and CO show excellent agreement with sun photometer aerosol optical depth (AOD) measurements, satellite CO columns observations and local monitoring stations data. From the model simulation results, we estimated that biomass burning contributes $12 \%$ of total black carbon and $16 \%$ of atmospheric CO in Hong Kong on annual average. South East Asia shows the largest influence to the black carbon and CO levels in Hong Kong, accounts for $11 \%$ of the total atmospheric black carbon and $8 \%$ of CO. Biomass burning in North East Asia and Africa also show significant impacts to Hong Kong. Elevated levels of atmospheric black carbon aerosols and CO were observed during springtime (March and April) which is mainly due to the enhancement of biomass burning contributions. Black carbon and CO originating from biomass burning sources are estimated to contribute $40 \%$ of atmospheric black carbon and $28 \%$ of CO in Hong Kong during March 2014. An investigation focusing on the biomass burning pollution episode during springtime suggests the intensified biomass burning activities in the Indochinese Peninsula are the major sources of black carbon and CO in Hong Kong during the time.
\end{abstract}

\section{INTRODUCTION}

Biomass burning is a global phenomenon which has long been known to affect both the climate and air quality. It includes forest fires, deliberate burning of forests to create agricultural lands and burning of crop residue. Biomass burning is a significant source of atmospheric greenhouse gases, trace gases and particulate matters, including carbon monoxide (CO) and carbonaceous aerosols (Crutzen and Andreae, 1990; Andreae and Merlet, 2001). These pollutants have both direct and indirect influences on the global atmospheric chemistry and climate system (Streets et al., 2003). Biomass burning activities take place in different regions at different times of the year (Lee et al., 2013). Pollutants emitted from biomass burning are not only causing local impacts, but also influencing regions far from the sources through long range transportation (Fishman et al., 1991; Lee et al., 2013; Chan and Chan, 2017). The spatial and temporal variations of the biomass burning emissions as well as their transportation are not well understood. Therefore, it is important to understand the transportation and the contributions of pollutants originated from biomass burning sources in different regions around the globe.

Transport model is a useful tool to investigate the emission sources and the transportation of pollutants in the atmosphere. It is able to provide quantitative estimations of the contributions of different pollutants from different sources in different regions. However, the emission sources are not well characterized and accurately estimated in some of the emission inventories used in the model (Liousse et al., 2010; Henriksson et al., 2014). In addition, the physical and chemical processes in the atmosphere are often simplified in the model which might not be able to fully

\footnotetext{
${ }^{*}$ Corresponding author
}

reproduce the reality. Therefore, the model results have to be validated and interpret together with different kind of measurements. In this study, we present a quantitative estimation of the impacts of biomass burning emissions from different source regions to the local air quality in Hong Kong using global chemistry transport model simulations, sun photometer measurements, satellite observations and local monitoring network data. In this study, we focus on the black carbon aerosols and $\mathrm{CO}$ originating from biomass burning sources in different regions. Detailed descriptions of the global chemistry transport model simulations as well as the other datasets used are presented. The global chemistry transport model simulations are validated against sun photometer measurements, satellite observations and local monitoring stations data. The biomass burning contributions of black carbon and $\mathrm{CO}$ from different source regions are estimated using the model results. In addition, a study focusing on the biomass burning pollution episode during spring 2014 is presented.

\section{METHODOLOGY}

\subsection{Global model simulations}

The Chemistry Transport Model (CTM) GEOS-Chem was used to simulate the transportation of biomass burning pollutants in the atmosphere. The model is a global three dimensional CTM which is driven by assimilated meteorological fields from the Goddard Earth Observing System (GEOS) of the National Aeronautics and Space Administration (NASA) Global Modeling Assimilation Office (GMAO) (Bey et al., 2001). In this study, the GEOS5-FP meteorological data with a horizontal resolution of $2.0^{\circ}$ (latitude) $\times 2.5^{\circ}$ (longitude), a vertical resolution of 72 hybrid pressure-sigma levels and temporal resolution of 1 hour 


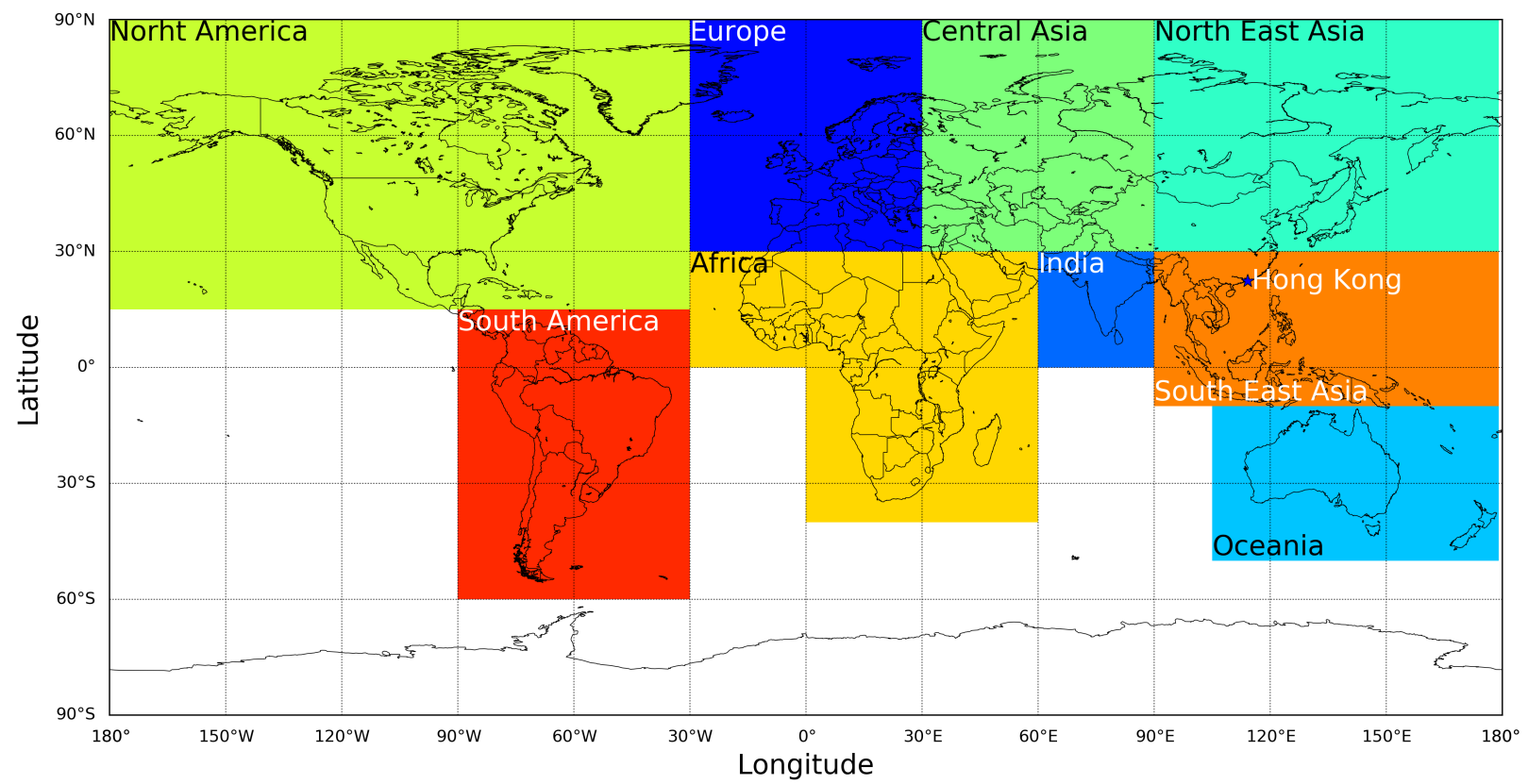

Figure 1. Emission source regions of biomass burning in the model. The asterisk marker indicates the location of Hong Kong.

were used to drive the CTM GEOS-Chem version 10-01. In total, there are 92 tracers included in the Universal troposphericstratospheric Chemistry eXtension (UCX) simulations (Eastham et al., 2014). Transportation of atmospheric components were calculated every 15 minutes in the model with both emission and chemistry time steps of 30 minutes.

In this study, we focus on the impacts of black carbon particles and $\mathrm{CO}$ directly emitted from biomass burning to the air quality in Hong Kong $\left(22.21^{\circ} \mathrm{N}, 114.26^{\circ} \mathrm{E}\right)$. Biomass burning emissions were divided into 9 major source regions, which are 1) South East Asia, 2) North East Asia, 3) India, 4) Central Asia, 5) Oceania, 6) Europe, 7) Africa, 8) North America and 9) South America. An illustration of the emission source regions classified in the model is shown in Figure 1. A multiple emission approach (Lee et al., 2013; Zhang et al., 2014; Chan and Chan, 2017) was used to identify the contribution of biomass burning emissions in each region to the local air quality in Hong Kong. Biomass burning emissions in each region were turned off in the sensitivity runs. By subtracting the simulation results of the sensitivity runs from the base case (which included all emissions), the contributions of biomass burning sources from each region were calculated. In this study, the simulations were carried out from January 2014 to Dec 2014 with 3 months (October to December 2013) of spun up prior to the simulations. The AODs and pollutant concentrations of the receptor site, i.e., Hong Kong, were calculated as the weighted average of the values over the 4 closest grid points in the model. Weighting of the grid point is defined as $1 / D^{2}$, where $D$ is the distance between the grid point and the receptor site.

\subsection{Sun photometer measurements}

Ground based passive remote sensing of aerosol optical properties was achieved by a sun photometer operated by the Hong Kong Polytechnic University $\left(22.21^{\circ} \mathrm{N}, 114.26^{\circ} \mathrm{E}\right)$ which is also part of the the AERosol RObotic NETwork (AERONET) (Holben et al., 1998). The sun photometer provides observations of aerosol optical properties at multiple wevelength channels (Holben et al., 2001). Aerosol properties are retrieved from the sun photometer measurement by an inversion algorithm developed by Dubovik and King (2000); Dubovik et al. (2006). In this study, cloud screened and quality assured level 2.0 data are used. Aerosol absorption optical depths (AAODs) at $439 \mathrm{~nm}$ retrieved from the sun photometer measurements are used to validate the GEOS-Chem black carbon simulations. Individual measurements were averaged to daily values in order to compare to the model results. Details of the AERONET and their retrieval algorithm for aerosol optical depths can be found in Holben et al. (1998); Dubovik and King (2000); Holben et al. (2001).

\subsection{Satellite observations}

The Atmospheric InfraRed Sounder (AIRS) is a hyperspectral grating spectrometer aboard on the second Earth Observing System (EOS2) polar-orbiting satellite providing wide range of atmospheric measurements for climate research and weather forecast (Chahine et al., 2006; Marshall et al., 2006). The instrument measures at 2378 infrared channels from $3.7 \mu \mathrm{m}$ up to $15.4 \mu \mathrm{m}$ with various spatial resolutions, providing measurement of greenhouse gases such as carbon dioxide $\left(\mathrm{CO}_{2}\right), \mathrm{CH}_{4}, \mathrm{CO}$ and $\mathrm{O}_{3}$. Daily level 3 product of $\mathrm{CO}$ total column from both daytime ascending and nighttime descending observations with spatial resolution of $1^{\circ} \times 1^{\circ}$ (AIRX3STD) are used in this study (McMillan et al., 2005), the data are available on the NASA Goddard Earth Sciences Data Information and Services Center (GES DISC).

The MODerate resolution Imaging Spectroradiometer (MODIS) satellite based instruments are passive nadir viewing imaging spectrometers (Salomonson et al., 1989) on board the Earth Observing System's (EOS) Terra and Aqua satellites. The instruments provide measurements at 36 discrete wavelength bands from $0.4 \mu \mathrm{m}$ up to $14.4 \mu \mathrm{m}$ with various spatial resolutions, providing global observation every 1 to 2 days. Fire Radiative Power (FRP) data product derived by the collection 6 MODIS active fire detection algorithm (Giglio et al., 2016) are used to identify areas associated with biomass burning activities. The algorithm uses the both MODIS Terra and Aqua observations at $4 \mu \mathrm{m}$ to retrieve the fire radiative power. In this study, cumulative fire radiative power data 
were used to investigate the springtime biomass burning pollution episode in Asia, the data are available on the Fire Information for Resource Management System (FIRMS).

\subsection{Ancillary data}

Ambient carbon monoxide (CO) data in Hong Kong were acquired from the air quality monitoring network of Hong Kong which is operated by the Environmental Protection Department (EPD). The air quality monitoring network comprises 13 ambient monitor stations and 3 road side monitor stations. Among the 13 ambient monitoring stations, 5 of them provide $\mathrm{CO}$ measurement data in 2014. These monitoring stations cover both urban and rural areas in Hong Kong, providing representative ambient measurement data. In this study, the ambient $\mathrm{CO}$ concentrations reported from the 5 monitoring stations were averaged to obtain representative values for the entire city. The ambient $\mathrm{CO}$ concentrations are measured by the gas filter correlation $\mathrm{CO}$ analyzer (Model T300, Teledyne API Ltd). The CO monitor is a NonDispersive InfraRed (NDIR) analyzer equipped with gas correlation filters to correct for the influences from other infrared absorbing gases (López and de Frutos, 1993). Details of the air quality monitoring network as well as the monitoring stations can be found on the website of the Hong Kong Environmental Protection Department (http://www.aqhi.gov.hk/en/monitoring-network/airquality-monitoring-network.html).

\section{RESULTS AND DISCUSSIONS}

\subsection{Validation of simulations}

The GEOS-Chem black carbon aerosol simulations are validated by comparing the modeled black carbon AODs to the aerosol absorption optical depths (AAODs) derived from the sun photometer observations. As black carbon particles are an effective radiation absorber, therefore, the AAODs are good indicators for detecting the black carbon aerosols in the atmosphere. Time series of the GEOS-Chem simulations of black carbon AODs and the sun photometer observations of AAODs over Hong Kong are shown in Figure 2a. Daily and monthly average data are shown. Both GEOS-Chem and sun photometer data show a similar variation pattern with peak values during springtime (March and April). Correlation between the GEOS-Chem simulations and the sun photometer observations of black carbon aerosols is shown in a scatter plot (Figure 2b). Daily and monthly averaged GEOS-Chem simulations show a good agreement with the sun photometer observations with Pearson correlation coefficient $(R)$ of 0.89 . The comparison result shows the model is able to reproduce the variation trend of sun photometer observations of atmospheric black carbon aerosols.

Satellite observations of CO total columns from the AIRS satellite are used to validate the GEOS-Chem simulation of CO in 2014. Time series of the GEOS-Chem simulations and AIRS satellite observations of $\mathrm{CO}$ total columns over Hong Kong are shown in Figure 3a. Daily and monthly average data are shown. Both the model simulations and satellite observations show a similar seasonal pattern with lower $\mathrm{CO}$ columns during summer and higher values in spring and winter. Correlation between the GEOSChem simulation and the AIRS satellite observation of total column $\mathrm{CO}$ is shown in a scatter plot (Figure 3b). Both daily and monthly averaged data show a good agreement with each other with Pearson correlation coefficient $(R)$ of 0.89 .
Ambient $\mathrm{CO}$ concentrations obtained from the local air quality monitoring network are used to compare to the $\mathrm{CO}$ concentrations at the lowest layer of the GEOS-Chem model results. Ambient $\mathrm{CO}$ measurements from 5 in-situ monitoring stations are averaged to obtain representative values to compare to the GEOChem simulations. Time series of the ambient $\mathrm{CO}$ concentrations derived from the GEOS-Chem simulations and the local air quality monitoring network are shown in Figure 4a. Correlation between model and measurement of surface $\mathrm{CO}$ concentrations is shown in a scatter plot (Figure 4b). The result shows an excellent agreement with Pearson correlation coefficient $(R)$ of 0.93 . The satellite and monitoring stations measurements comparisons indicate the model is able to reproduce the variation trend of the atmospheric $\mathrm{CO}$ and it is reliable to identify the biomass burning contribution of $\mathrm{CO}$ in Hong Kong.

\subsection{Biomass burning activities over different regions}

Satellite observations of fire radiative power are used to identify areas associated with biomass burning activities. Time series of the MODIS cumulative fire radiative power over different source regions is shown in Figure 5. Biomass burning activities in different areas show different seasonal characteristic due to the differences in climate and meteorological conditions. Seasonal variations of biomass burning activities show a bimodal pattern over Africa with peaks during winter of the northern and southern hemisphere. Biomass burning activities are mainly concentrated in the northern hemisphere part of Africa from November to March while the peak from April to October is related to the biomass burning activities in the southern hemisphere part of Africa. It should be noted that emissions in the southern hemisphere only show negligible effect on the northern hemisphere. Biomass burning in South East Asia peaks in spring (March and April). Fire radiative power observations over North East Asia also show elevated biomass burning activities during springtime (April), another peak can also be observed during summer (July). The seasonal variation patterns reflect the actual agricultural practices in different regions.

\subsection{Biomass burning contribution of black carbon and $\mathrm{CO}$ in Hong Kong}

In this section, we focus on the impacts of black carbon aerosols and atmospheric $\mathrm{CO}$ originating from biomass burning sources in different regions to the black carbon and $\mathrm{CO}$ levels over Hong Kong. Time series of biomass burning contribution of black carbon aerosols from different source regions is shown in Figure 6. Model result shows black carbon from biomass burning sources contributing to $12 \%$ of the total black carbon in Hong Kong on annual average and the biomass burning contribution can goes up to above $50 \%$ during some episode days in spring, i.e. March and April. Spatial analysis of the model results indicates that biomass burning sources in South East Asia show the largest influence to the black carbon levels in Hong Kong, contributing about $11.5 \%$ of the total black carbon in Hong Kong on annual average. Second largest contributing region is the North East Asia with annual averaged contribution of $0.3 \%$. Biomass burning activities in Asia are mainly concentrated in springtime due to the agriculture patterns (see Figure 5), biomass burning sources in Asia contributed over $30 \%$ of the total black carbon in Hong Kong in March and April. The biomass burning contribution could reach as high as $60 \%$ for some episode days in spring. Although Africa is far away from Hong Kong, due to the significant biomass burning emissions and stronger westerlies in the upper troposphere in winter, black carbon from biomass burning sources in Africa 

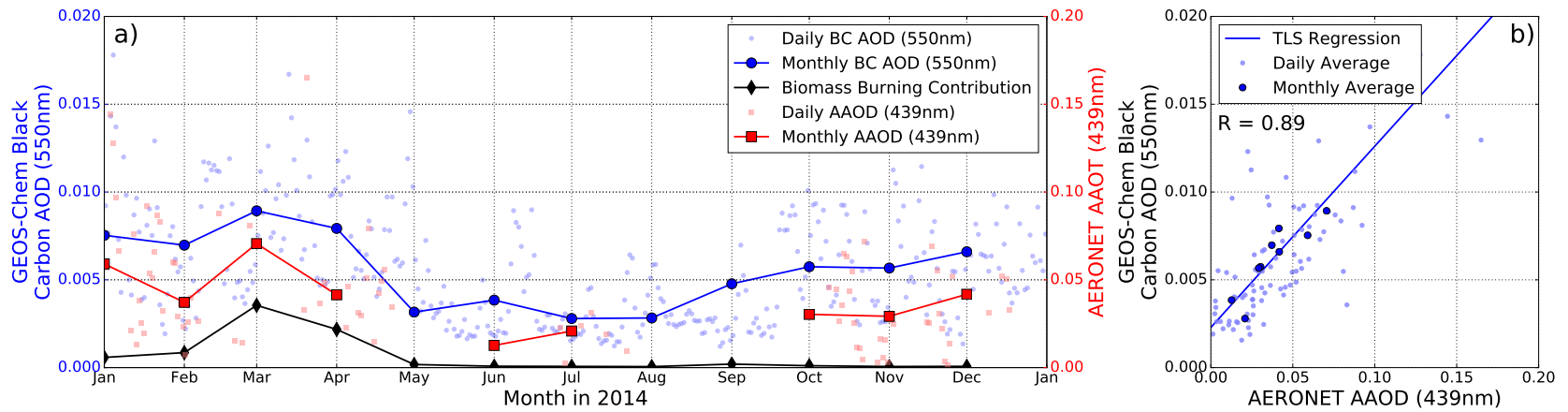

Figure 2. (a) Time series of the GEOS-Chem simulation of black carbon aerosol optical depths (AODs) and the sun photometer observation of aerosol absorption optical depths over Hong Kong. The contribution of black carbon AODs originating from biomass burning sources is also shown for reference. (b) Comparison of GEOS-Chem simulation of black carbon AODs and sun photometer observation aerosol absorption optical depths over Hong Kong. Daily and monthly average data are shown. The total least squares regression line is calculated based on the monthly average data.
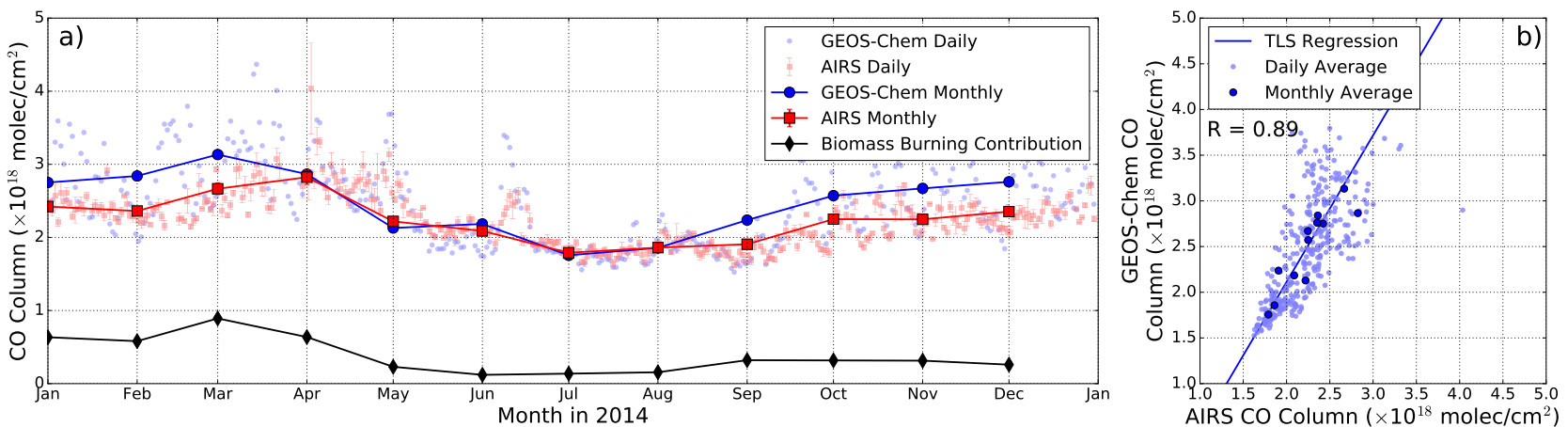

Figure 3. (a) Time series of the GEOS-Chem simulation and AIRS satellite observations of CO total columns over Hong Kong. The contribution of atmospheric $\mathrm{CO}$ originating from biomass burning sources is also shown for reference. (b) Comparison of

GEOS-Chem simulation and AIRS satellite observation of CO total columns over Hong Kong. Daily and monthly average data are shown. The total least squares regression line is calculated based on the monthly average data.
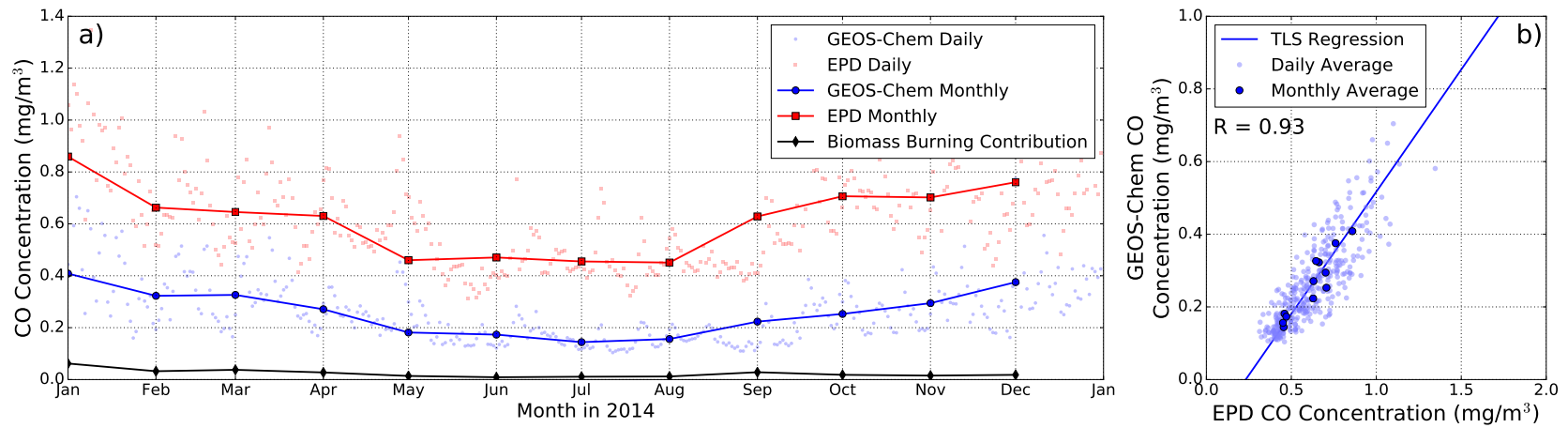

Figure 4. (a) Time series of the GEOS-Chem simulation and the air quality monitoring network measurement of ambient CO concentrations in Hong Kong. The contribution of biomass burning CO is also shown for reference. (b) Comparison of GEOS-Chem simulation and air quality monitoring network measurement of ambient CO concentrations in Hong Kong. Daily and monthly average data are shown. The total least squares regression line is calculated based on the monthly average data.

contributes up to $1 \%$ of the total black carbon in Hong Kong during wintertime, i.e., January, February and December. As the other source regions are further away from Hong Kong and their biomass burning emissions are less significant, therefore, their contributions are expected to be low (below $0.2 \%$ ) on annual average. In addition, the atmospheric lifetime of black car- bon aerosol is rather short (about 6 - 10 days) (Cooke and Wilson, 1996), thus, it is less likely to be transported far away from the sources.

The atmospheric $\mathrm{CO}$ originating from biomass burning sources shows different characteristic compared to the black carbon aerosols. Time series of the contributions of atmospheric $\mathrm{CO}$ from biomass 


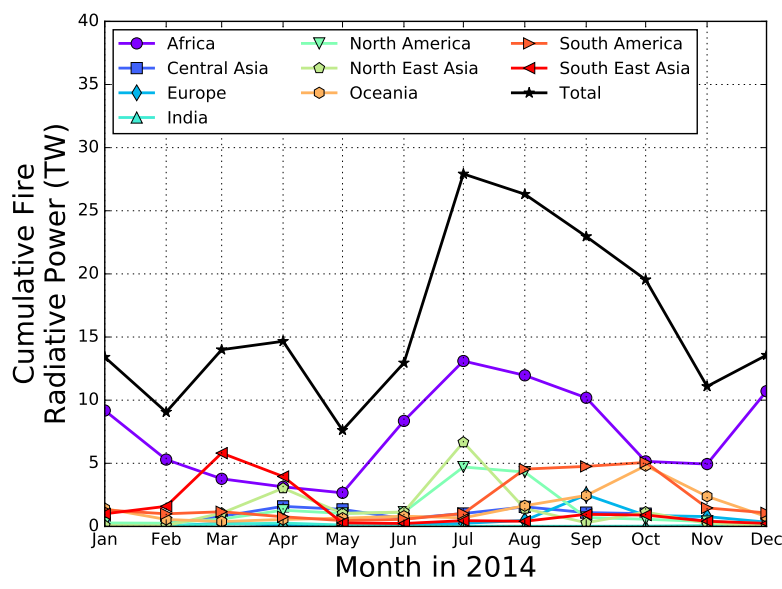

Figure 5. Time series of the MODIS cumulative fire radiative power over different biomass burning source regions.

burning sources in different regions is shown in Figure 7. Biomass burning contributes $\sim 15.7 \%$ of the total atmospheric $\mathrm{CO}$ over Hong Kong on annual average and the contribution could goes up to $30 \%$ in spring, i.e. March and April. Significant biomass burning contributions in spring are related to the enhanced biomass burning activities in Asia. In terms of biomass burning source regions, South East Asia has the greatest impact on Hong Kong, which contributed about $7.8 \%$ of the total atmospheric $\mathrm{CO}$ in Hong Kong on annual average. Biomass burning activities in South East Asia show the largest impact to Hong Kong in spring with contribution up to $\sim 20 \%$ (March). Annually averaged contribution of biomass burning $\mathrm{CO}$ from Africa is about $3.0 \%$ with maximum contribution of $\sim 5.0 \%$ in January and February. Enhanced biomass burning activities and the westerly jetstreams in the upper troposphere during winter result in higher contribution from Africa. In addition, the atmospheric lifetime of $\mathrm{CO}$ varies from 6 months up to 5 years (Jaffe, 1968; Wang and Prinn, 1999), which is much longer than that of black carbon aerosols. Therefore, the $\mathrm{CO}$ released into the atmosphere can be transported far away from the sources. Biomass burning sources in North East Asia contribute about $1 \%$ of the total CO column in Hong Kong on annual average. As the emission in other regions are less significant and they are further away from Hong Kong, their contributions are in general lower (less than $1 \%$ on annual average). However, the atmospheric lifetime of $\mathrm{CO}$ is longer than that of black carbon, the $\mathrm{CO}$ contribution from remote sources are higher than that of black carbon.

\subsection{Springtime biomass burning pollution episode in Asia}

During the springtime biomass burning episode, biomass burning activities were intensifies over the Indochinese Peninsula, India and the Riau province of Indonesia while several biomass burning hotspots can be observed in the northern Asia during April 2014. This is revealed by the MODIS fire radiative power observations as shown in Figure 8. Intensified biomass burning over the the Riau province of Indonesia were mainly related to a serious forest fire in March 2014. Cluster analysis of the 48 hours backward trajectories calculated by the HYSPLIT model is used to further evaluate the role of air mass transport during the pollution episode observed in Hong Kong. The backward trajectories in March are grouped into 5 different clusters (see Figure 8a) while the trajectories in April are grouped into 4 different clusters (see Figure $8 b$ ). The percentage of occurrence are indicated.
Both the cluster analysis results in March and April show the air masses were mainly $(>60 \%)$ originating from the Indochinese Peninsula where biomass burning activities were more active. The result implies the black carbon and $\mathrm{CO}$ were mainly from the transported biomass burning emissions over the Indochinese Peninsula, while the forest fire in Indonesia only shows minor impacts to Hong Kong.

In order to have a better insight of the impacts of biomass burning emissions in South East Asia to other regions, we have looked at the spatial distribution of black carbon and $\mathrm{CO}$ originated from biomass burning sources in South East Asia in March 2014 (see Figure 9). Both black carbon and $\mathrm{CO}$ show elevated values over the Indochinese Peninsula and the Riau province of Indonesia, which matched the spatial distribution patterns of the MODIS fire radiative power observations. The biomass burning pollutants from the Indochinese Peninsula mainly transported to the east and influencing Hong Kong, Taiwan as well as the Southern part of Japan. A small portion of the pollutants were transported intercontinentally through the Pacific Ocean and reached the North America. In contrast, pollutants from Indonesia were carried by the easterly jetstreams to the west, traversing through the Indian Ocean and reached Africa. The result indicates the biomass burning emissions do not only show local impacts, but also can be transported intercontinentally and influence the atmospheric system in a global scale.

\section{SUMMARY AND CONCLUSIONS}

In this study, we present a quantitative estimation of the impacts of biomass burning emissions from different source regions to the local air quality in Hong Kong in 2014 using global chemistry transport model simulations, ground based remote sensing measurements, satellite observations and local monitoring network data. This study focuses on two major biomass burning pollutants, namely black carbon aerosols and carbon monoxide (CO). The model simulations of atmospheric black carbon and $\mathrm{CO}$ are validated by sun photometer aerosol optical depth (AOD) measurements, satellite $\mathrm{CO}$ columns observations and local monitoring stations data. The model simulations and observations show good consistency with each other. The results indicate the model is able to reproduce the variation of atmospheric black carbon and $\mathrm{CO}$ and it is accurate for the estimation of the biomass burning contributions.

The variations of biomass burning activities over different regions were indicated by the satellite observations of fire radiative power. The contributions of black carbon aerosols and $\mathrm{CO}$ from biomass burning sources in different regions are estimated by the global chemistry transport model GEOS-Chem with a multiple emission approach. Model simulations show biomass burning contributes to $12 \%$ of the total black carbon in Hong Kong on annual average and the contribution is the highest during spring with monthly averaged contribution of $40 \%$ in March 2014. The contribution can even reach up to $60 \%$ during some episode days. South East Asia is identified as the major contributing source region of biomass burning black carbon, accounting for more than $95 \%$ of the total biomass burning black carbon in Hong Kong. CO emitted from biomass burning sources shows a different contribution profiles compared to that of the black carbon. We estimated biomass burning contributes to $16 \%$ of the total $\mathrm{CO}$ columns in Hong Kong on annual average and the contribution goes up in spring with monthly averaged contribution of $\sim 28 \%$ in March. In term of source regions, South East Asia is identified 

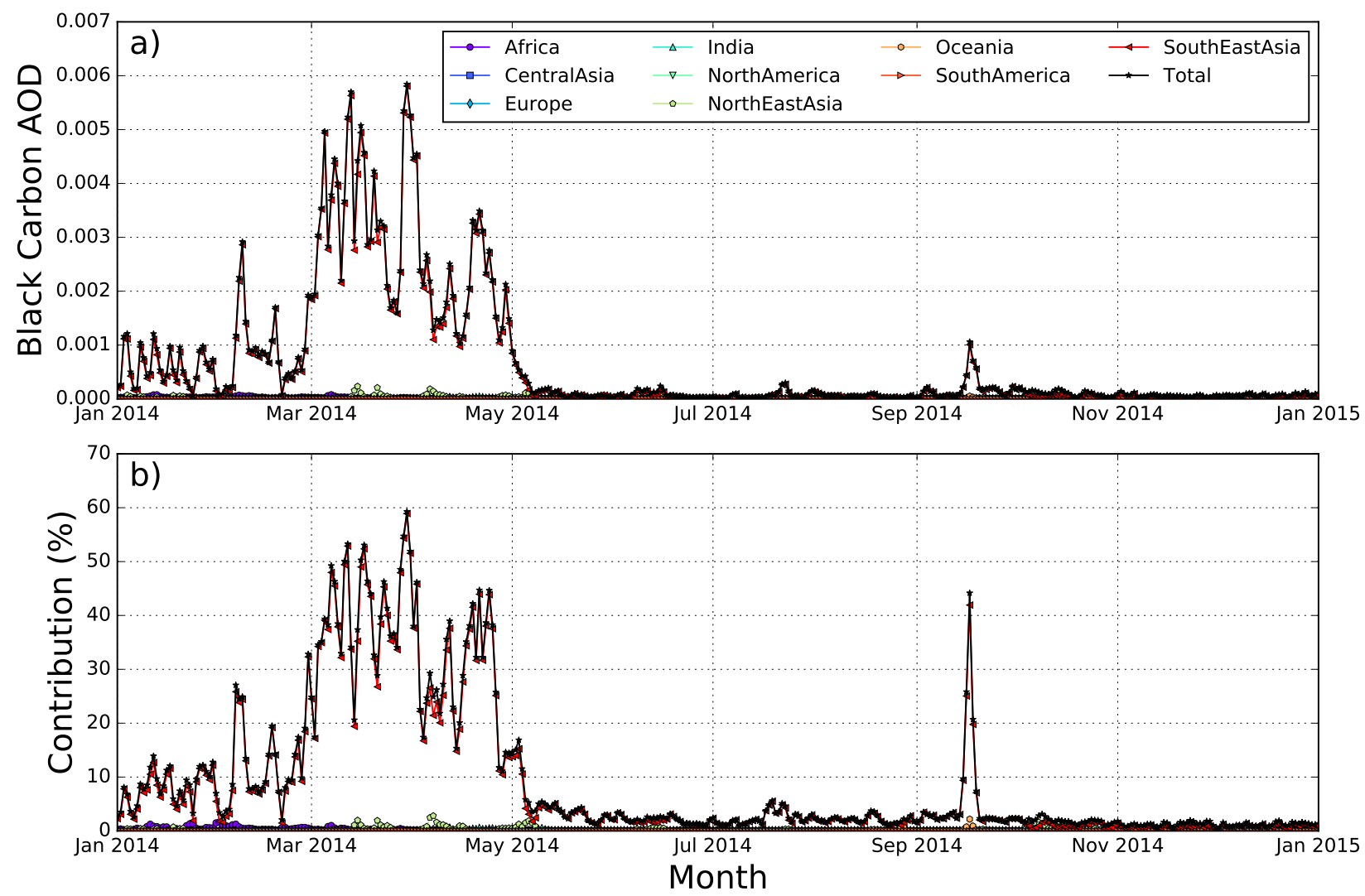

Figure 6. The absolute contribution of biomass burning black carbon AODs from different source regions (a) and their relative contribution to the total black carbon AODs (b) over Hong Kong.

as the major contributor of biomass burning $\mathrm{CO}$, accounting for $\sim 50 \%$ of the total biomass burning $\mathrm{CO}$ in Hong Kong on annual average.

In addition, a study focusing on the biomass burning pollution episode during spring (March and April) 2014 is presented. Elevated levels of black carbon and $\mathrm{CO}$ were detected during the time. The biomass burning contributions of black carbon and $\mathrm{CO}$ in March 2014 are estimated to be $40 \%$ and $28 \%$, respectively. In which, $99 \%$ and $70 \%$ of the biomass burning black carbon and $\mathrm{CO}$ are coming from South East Asia. Fire radiative power (FRP) observations from the MODIS satellite reveals biomass burning activities were more intensified over the Indochinese Peninsula, India and the Riau province of Indonesia. Cluster analysis of the backward trajectories calculated by the HYSPLIT model indicates the air masses were mainly originated from the Indochinese Peninsula. The result implies the enhanced black carbon and $\mathrm{CO}$ were mainly coming from the biomass burning emissions in the Indochinese Peninsula.

\section{ACKNOWLEDGEMENTS}

We thank Prof. Janet Elizabeth Nichol and her colleagues for their effort in establishing and maintaining the AERONET site. The authors would also like to thank the National Oceanic and Atmospheric Administration (NOAA) Air Resources Laboratory (ARL) for the provision of the HYSPLIT transport and dispersion model used in this publication. The work described in this paper was supported by the Marie Curie Initial Training Network of the European Seventh Framework Programme (Grant No. 607905).

\section{References}

Andreae, M. O. and Merlet, P., 2001. Emission of trace gases and aerosols from biomass burning. Global Biogeochemical Cycles 15(4), pp. 955-966.

Bey, I., Jacob, D. J., Yantosca, R. M., Logan, J. A., Field, B. D., Fiore, A. M., Li, Q., Liu, H. Y., Mickley, L. J. and Schultz, M. G., 2001. Global modeling of tropospheric chemistry with assimilated meteorology: Model description and evaluation. Journal of Geophysical Research: Atmospheres 106(D19), pp. 23073-23095.

Chahine, M. T., Pagano, T. S., Aumann, H. H., Atlas, R., Barnet, C., Blaisdell, J., Chen, L., Divakarla, M., Fetzer, E. J., Goldberg, M., Gautier, C., Granger, S., Hannon, S., Irion, F. W., Kakar, R., Kalnay, E., Lambrigtsen, B. H., Lee, S.Y., Marshall, J. L., McMillan, W. W., McMillin, L., Olsen, E. T., Revercomb, H., Rosenkranz, P., Smith, W. L., Staelin, D., Strow, L. L., Susskind, J., Tobin, D., Wolf, W. and Zhou, L., 2006. AIRS: Improving weather forecasting and providing new data on greenhouse gases. Bulletin of the American Meteorological Society 87(7), pp. 911-926.

Chan, K. L. and Chan, K. L., 2017. Aerosol optical depths and their contributing sources in Taiwan. Atmospheric Environment 148, pp. $364-375$.

Cooke, W. F. and Wilson, J. J. N., 1996. A global black carbon aerosol model. Journal of Geophysical Research: Atmospheres 101(D14), pp. 19395-19409.

Crutzen, P. J. and Andreae, M. O., 1990. Biomass burning in the tropics: Impact on atmospheric chemistry and biogeochemical cycles. Science 250(4988), pp. 1669-1679. 

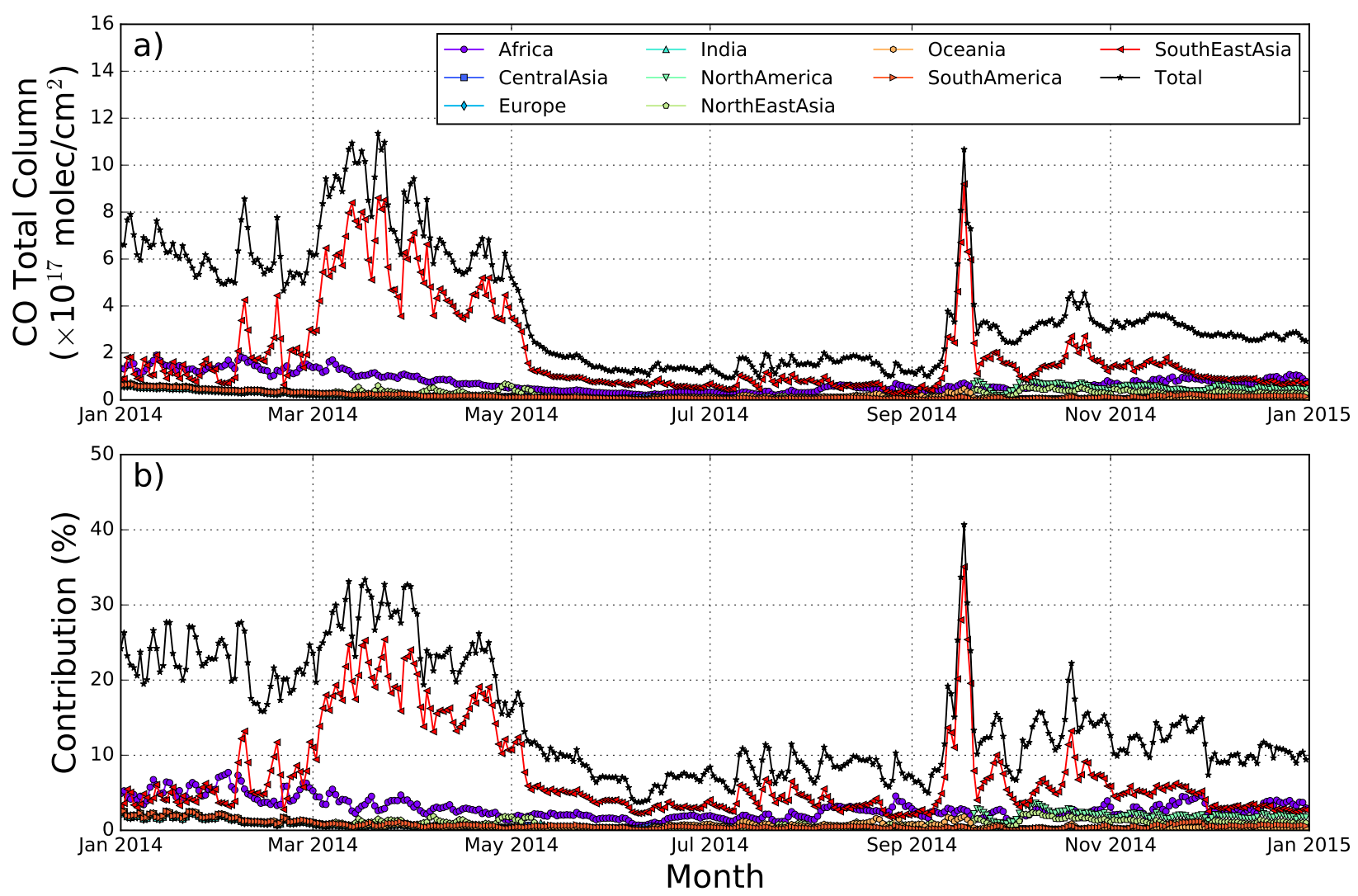

Figure 7. The absolute contribution of biomass burning CO total columns from different source regions (a) and their relative contribution to the CO total columns (b) over Hong Kong.

Dubovik, O. and King, M. D., 2000. A flexible inversion algorithm for retrieval of aerosol optical properties from sun and sky radiance measurements. Journal of Geophysical Research: Atmospheres 105(D16), pp. 20673-20696.

Dubovik, O., Sinyuk, A., Lapyonok, T., Holben, B. N., Mishchenko, M., Yang, P., Eck, T. F., Volten, H., Muñoz, O. Veihelmann, B., van der Zande, W. J., Leon, J.-F., Sorokin, M. and Slutsker, I., 2006. Application of spheroid models to account for aerosol particle nonsphericity in remote sensing of desert dust. Journal of Geophysical Research: Atmospheres. D11208.

Eastham, S. D., Weisenstein, D. K. and Barrett, S. R., 2014. Development and evaluation of the unified troposphericstratospheric chemistry extension (UCX) for the global chemistry-transport model geos-chem. Atmospheric Environment 89, pp. 52-63.

Fishman, J., Cros, B. et al., 1991. Identification of widespread pollution in the southern hemisphere deduced from satellite analyses. Science 252(5013), pp. 1693.

Giglio, L., Schroeder, W. and Justice, C. O., 2016. The collection 6 MODIS active fire detection algorithm and fire products. Remote Sensing of Environment 178, pp. 31-41.

Henriksson, S. V., Pietikäinen, J.-P., Hyvärinen, A.-P., Räisänen, P., Kupiainen, K., Tonttila, J., Hooda, R., Lihavainen, H., O'Donnell, D., Backman, L., Klimont, Z. and Laaksonen, A., 2014. Spatial distributions and seasonal cycles of aerosol climate effects in India seen in a global climate-aerosol model. Atmospheric Chemistry and Physics 14(18), pp. 10177-10192.
Holben, B., Eck, T., Slutsker, I., Tanre, D., Buis, J., Setzer, A., Vermote, E., Reagan, J., Kaufman, Y., Nakajima, T., Lavenu, F., Jankowiak, I. and Smirnov, A., 1998. AERONET - a federated instrument network and data archive for aerosol characterization. Remote Sensing of Environment 66(1), pp. 1-16.

Holben, B. N., Tanre, D., Smirnov, A., Eck, T. F., Slutsker, I., Abuhassan, N., Newcomb, W. W., Schafer, J. S., Chatenet, B., Lavenu, F., Kaufman, Y. J., Castle, J. V., Setzer, A., Markham, B., Clark, D., Frouin, R., Halthore, R., Karneli, A., O'Neill, N. T., Pietras, C., Pinker, R. T., Voss, K. and Zibordi, G., 2001. An emerging ground-based aerosol climatology: Aerosol optical depth from AERONET. Journal of Geophysical Research: Atmospheres 106(D11), pp. 12067-12097.

Jaffe, L. S., 1968. Ambient carbon monoxide and its fate in the atmosphere. Journal of the Air Pollution Control Association 18(8), pp. 534-540.

Lee, Y., Lam, Y., Kuhlmann, G., Wenig, M., Chan, K., Hartl, A. and Ning, Z., 2013. An integrated approach to identify the biomass burning sources contributing to black carbon episodes in Hong Kong. Atmospheric Environment 80, pp. 478-487.

Liousse, C., Guillaume, B., Grégoire, J. M., Mallet, M., Galy, C., Pont, V., Akpo, A., Bedou, M., Castéra, P., Dungall, L., Gardrat, E., Granier, C., Konaré, A., Malavelle, F., Mariscal, A., Mieville, A., Rosset, R., Serça, D., Solmon, F., Tummon, F., Assamoi, E., Yoboué, V. and Van Velthoven, P., 2010. Updated African biomass burning emission inventories in the framework of the AMMA-IDAF program, with an evaluation of combustion aerosols. Atmospheric Chemistry and Physics 10(19), pp. 9631-9646. 

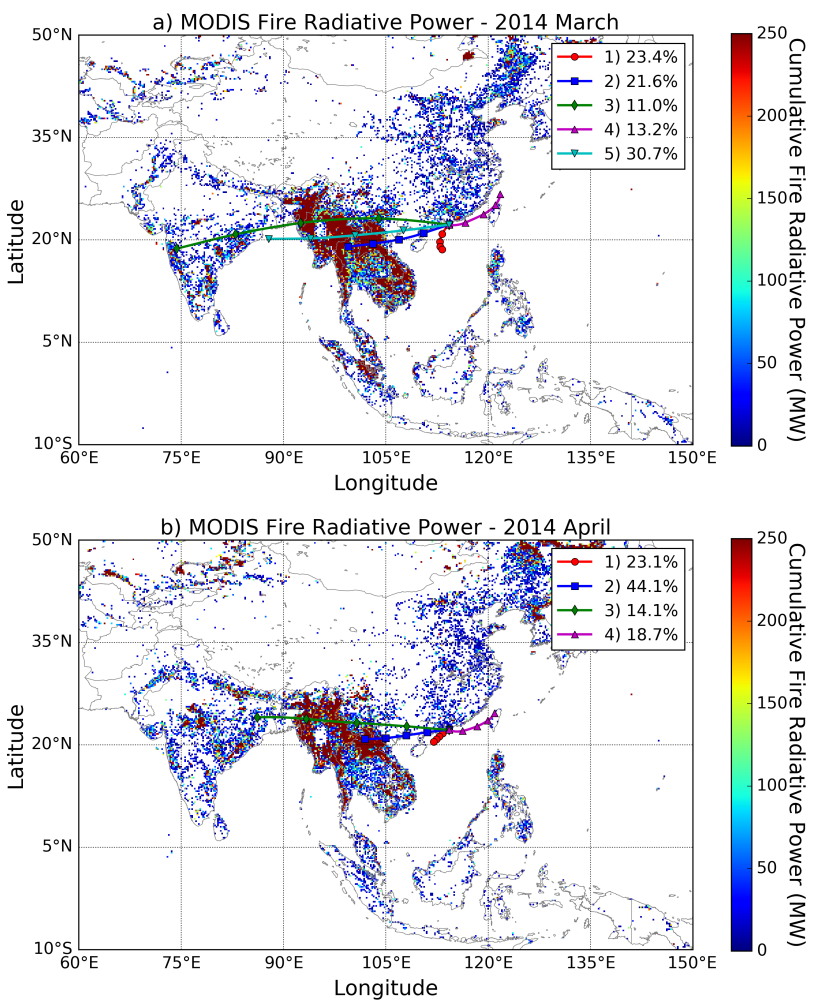

Figure 8. MODIS cumulative fire radiative power over Asia in (a) March and (b) April 2014 overlaid with the cluster analysis of the 48 hours backward trajectories. The percentage of occurrence of each cluster is indicated.
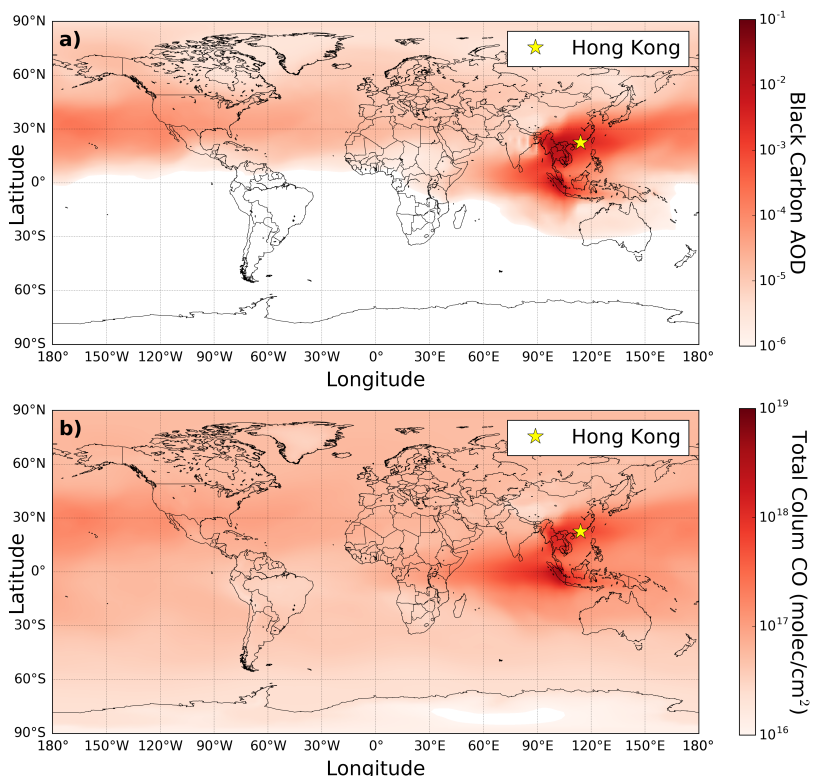

Figure 9. Spatial distribution of biomass burning (a) black carbon and (b) CO contributed by South East Asia in March 2014. The asterisk marker indicates the location of Hong Kong.

López, F. and de Frutos, J., 1993. Multispectral interference filters and their application to the design of compact nondispersive infrared gas analysers for pollution control. Sensors and Actuators A: Physical 37-38(0), pp. 502-506.
Marshall, J. L., Jung, J., Derber, J., Chahine, M., Treadon, R., Lord, S. J., Goldberg, M., Wolf, W., Liu, H. C., Joiner, J., Woollen, J., Todling, R., van Delst, P. and Tahara, Y., 2006. Improving global analysis and forecasting with airs. Bulletin of the American Meteorological Society 87(7), pp. 891-894.

McMillan, W. W., Barnet, C., Strow, L., Chahine, M. T., McCourt, M. L., Warner, J. X., Novelli, P. C., Korontzi, S., Maddy, E. S. and Datta, S., 2005. Daily global maps of carbon monoxide from nasa's atmospheric infrared sounder. Geophysical Research Letters. L11801.

Salomonson, V., Barnes, W., Maymon, P., Montgomery, H. and Ostrow, H., 1989. MODIS: advanced facility instrument for studies of the earth as a system. Geoscience and Remote Sensing, IEEE Transactions on 27(2), pp. 145-153.

Streets, D. G., Yarber, K. F., Woo, J.-H. and Carmichael, G. R., 2003. Biomass burning in Asia: Annual and seasonal estimates and atmospheric emissions. Global Biogeochemical Cycles. 1099.

Wang, C. and Prinn, R. G., 1999. Impact of emissions, chemistry and climate on atmospheric carbon monoxide: $100-\mathrm{yr}$ predictions from a global chemistryclimate model. Chemosphere Global Change Science 1(1-3), pp. 73-81.

Zhang, Z., Wenig, M., Zhou, W., Diehl, T., Chan, K. L. and Wang, L., 2014. The contribution of different aerosol sources to the aerosol optical depth in Hong Kong. Atmospheric Environment 83 , pp. $145-154$. 